\title{
RADIATION EFFECTS ON RAT TESTES
}

\author{
V. STUDIES ON LYSOSOMAL ENZYMES (ACID PHOSPHATASE \\ AND ACID DNAsE) AND THEIR PHYSIOLOGICAL SIGNIFIGANCE \\ FOLLOWING PARTIAL BODY GAMMA-IRRADIATION
}

\author{
G. S. GUPTA AND S. R. BAWA \\ Department of Biophysics, Panjab University, Chandigarh, India
}

(Received 2nd October 1974)

\begin{abstract}
Summary. Acid phosphatase is present in the nucleus and cytoplasm of cells in the seminiferous tubules and the interstitium of rat testes. The effect of irradiation on acid phosphatase is dependent on the environmental temperature and the dose of irradiation. It appears that initial rise in the enzyme at a low radiation dose and a high environmental temperature or at a high dose and low temperature is associated with a lysosomal breakdown of the germinal cells of the testes. A decrease in acid phosphatase in the advanced stages of radiation injury is a secondary radiation effect which may lead to decreased metabolic synthesis of phosphate esters owing to the unavailability of orthophosphate in the testicular tubules. The reduced acid phosphatase activity can be detected in the seminiferous tubules, suggesting that the enzyme activity is related to the state of the germ cell population. An initial increase in acid phosphatase is matched by an initial rise in acid DNAse within hours of irradiation, further suggesting that there is radiation interaction with the cells of the germinal epithelium. The enhanced activity of DNAse following a 2nd week of irradiation at $2000 \mathrm{R}$ confirms the phagocytic activity of the non-germinal cells.
\end{abstract}

\section{INTRODUCTION}

The study of testicular metabolic processes after ionising irradiation is complicated by difficulties in interpretation owing to the presence of a variety of different cells and the interplay of the pituitary (Steinberger, 1964). Though enzymatic patterns have often been related to changes in cell types during progressive stages of spermatogenesis (Males \& Turkington, 1971), there are few studies on the metabolic and enzymatic pattern of irradiated testes (Steinberger \& Nelson, 1957; Steinberger \& Wagner, 1961; Pecora \& Arate, 1964; Ito, 1966; Gupta \& Bawa, 1970, 1971, 1974a, 1974b, 1975). The early effects of radiation injury are often related to a decrease in the content and synthesis of nucleic acids (Alekseeva \& Timofeeva, 1959; Valenta \& Kolousek, 1963; Sapsford, 1965; Gupta \& Bawa, 1970, 1974b). Okada (1970) emphasized the rôle of ionic permeability and release of lysosomal enzymes in cell degeneration 
following irradiation. The present observations concern the study of lysosomal enzymes in irradiated testes and suggest that the changes in these enzymes may be related to the radiation injury of the germinal epithelium and to the phagocytic activity of the non-germinal cells.

\section{MATERIALS AND METHODS}

Radiation procedure and treatment of tissues

Normal white albino male rats weighing 150 to $200 \mathrm{~g}$ and of a single strain were assigned to thirty-four groups, with four to six rats in each group. The rats were anaesthetized by intraperitoneal injections of pentobarbitone sodium (25 mg/kg body weight) and the body inferior to the penis of each rat was irradiated with a single surface dose of $\gamma$-radiation at a distance of $65 \mathrm{~cm}$ from a cobalt-60 source (Gupta \& Bawa, 1974a) shielded in a Theratron (Canada) radiotherapy unit. The total surface dose of radiation varied from 720 to 6000 $\mathrm{R}$. Four to six sham-irradiated rats acted as controls for each set of observations. During and after irradiation, the animals were normally maintained at a temperature of 30 to $40^{\circ} \mathrm{C}$, but in one set of experiments the rats were kept at an environmental temperature of 12 to $25^{\circ} \mathrm{C}$. For those rats observed over a period of 11 months, the temperature ranged between 12 and $40^{\circ} \mathrm{C}$. Food was withdrawn 6 to $8 \mathrm{hr}$ before the rats were killed by decapitation. The testes of the rats in each group were pooled and frozen. A randomized portion of parenchymal tissue was homogenized in a Potter-Elvehjem homogenizer to yield 5 to $10 \%$ aqueous homogenates. Whole homogenate was used for the assay of acid phosphatase but the supernatant fraction obtained after centrifugation at $3200 \mathrm{~g}$ was used for assay of acid DNAse. The assay values for the enzymes of the rats in the control groups were pooled and their mean values with standard deviations were determined. This mean value of the enzyme was assumed to be the mean for normal rats. The relative values of the irradiated rats compared to those of the controls were also plotted separately for convenience of interpretation.

\section{Separation of seminiferous tubules}

Partial body irradiation of the testes with a total dose of $720 \mathrm{R}$ was performed according to the method described above. Thirty days after irradiation, the seminiferous tubules of the testes of normal and irradiated rats were separated from the interstitium according to the method of Hall, Irby \& de Kretser (1969) in Ringer bicarbonate buffer. When all the tubules were removed, the interstitial tissue in the remaining portion consisted of Leydig cells, connective tissue and blood vessels. Acid phosphatase activity was determined in homogenates of the two different portions.

\section{Subcellular fractionation}

Mitochondria from homogenates of whole testes were fractionated according to the method described by Clausen (1969) using 0.33 M-sucrose as the dispersion medium. The nuclear fraction separated at $900 \mathrm{~g}$ (Fraction I), the mitochondrial fraction separated at 10,000 $\mathrm{g}$ (Fraction II) and the remaining 
cytosol with microsomes intact (Fraction III) was analysed separately for acid phosphatase activity.

Determination of acid phosphatase (orthophosphoric monoester phosphohydrolase, EC 3.1.3.2)

A volume $(1 \mathrm{ml})$ of $\beta$-glycerophosphate was hydrolysed by $0.5 \mathrm{ml}$ tissue homogenate for $1 \mathrm{hr}$ at $37^{\circ} \mathrm{C}$ and $\mathrm{pH} 5.6$ (acetate buffer). The reaction was terminated by $0.5 \mathrm{ml}$ of $10 \%$ trichloracetic acid (TCA), and orthophosphate was determined in the supernatant. A unit of enzyme activity was defined as the amount which liberated $1 \mu \mathrm{g}$ orthophosphate in $1 \mathrm{hr}$ at $37^{\circ} \mathrm{C}$ (Gupta \& Bawa, 1970).

\section{Determination of acid deoxyribonuclease}

The activity of DNAse II (deoxyribonucleate 3'-oligonucleotidohydrolase: EC 3.1.4.6) was determined by a modified method of Kurnick \& Sandeen (1960). The concentrations of DNA as substrate, described in the original technique of Kurnick \& Sandeen (1960), did not give appreciable activity of acid DNAse. The concentrations of the substrate described in the present investigation were optimum concentrations for testicular DNAse. The substrate mixture consisted of $2 \mathrm{ml}$ aqueous DNA $(8 \mathrm{mg} / \mathrm{ml}), 2 \mathrm{ml}$ methyl green $(0.4 \%), 4 \mathrm{ml}$ acetate buffer ( $\mathrm{pH} 4.6,0.05 \mathrm{~N}), 2 \mathrm{ml}$ magnesium chloride $(0.64 \mathrm{M})$, distilled water and $0.02 \mathrm{ml}$ aqueous sodium ethyl mercurithiosalicylate (1\% merthiolate). The incubation medium contained $1.6 \mathrm{ml}$ substrate mixture and $0.4 \mathrm{ml}$ tissue homogenate. At $2 \mathrm{hr}$ after incubation, $2 \mathrm{ml}$ of a mixture of sodium citrate and 0.05 M-tris-buffer, $\mathrm{pH} 7.5(1: 3, \mathrm{v} / \mathrm{v})$ was added. The mixture was stirred and allowed to stand in subdued light at room temperature overnight to assure complete fading off of free methyl green. The optical density was read at $640 \mathrm{~nm}$. The unit of enzyme activity was defined as that which caused a reduction in the optical density of $1 \cdot 0 / \mathrm{min} / \mathrm{ml}$ reaction mixture at $37^{\circ} \mathrm{C}$.

\section{Other determinations}

The methods of Lowry, Rosebrough, Farr \& Randall (1951) and Fiske \& Subbarow (1925) were used for the assays of protein and phosphorus respectively. Colour determinations were made in a spectronic-20 colorimeter spectrophotometer. Details regarding the number of animals and the analyses are given in the legends of the Text-figures.

\section{RESULTS}

\section{Acid phosphatase}

The normal mean value \pm S.D. for acid $\beta$-glycerophosphatase in the testes was $133 \pm 19$ units/100 $\mathrm{mg}$ tissue and $35 \cdot 2 \pm 8 \cdot 3$ units/mg protein (Text-figs 1 and 2). An increase in the specific activity of the enzyme was demonstrable during the first week of irradiation at both lethal and sub-lethal doses (Textfig. 2). Though this increase in the activity fell within the normal range for rat testes, it was significant $(P<0.05)$ when compared with the results of pooled analyses of the data for the sham-irradiated controls. After the first week, the 
acid phosphatase activity decreased and became constant 10 to 24 days after irradiation (Text-fig. 2). The activity of the enzyme/testis decreased for 10 to 24 days, but maintained reasonably constant values thereafter (Text-fig. 2c). The effect of different doses of irradiation on acid phosphatase activity is shown in Text-fig. 3. The maximum damage/testis occurred at $2000 \mathrm{R}$. The activity/mg protein increased slightly between 4000 and $6000 \mathrm{R}$, but the increase in the enzyme activity/testis beyond $2000 \mathrm{R}$ was apparently only slight.

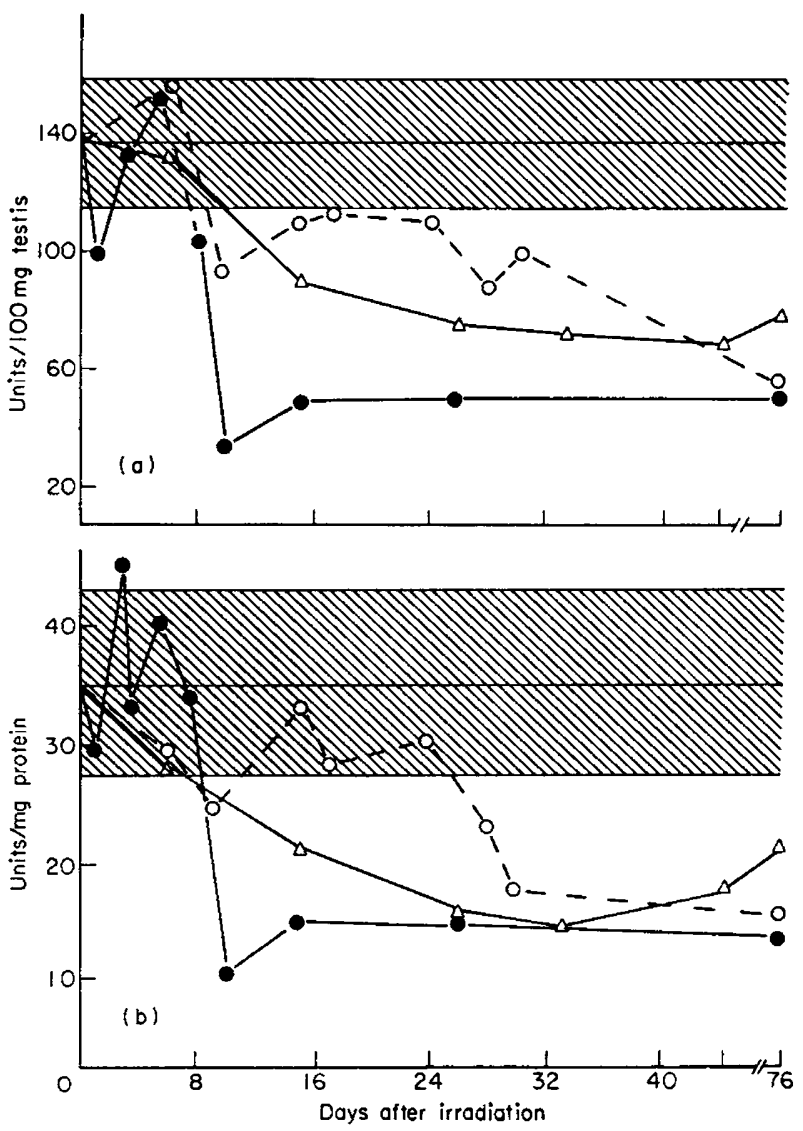

TexT-FIG. 1. Acid phosphatase activity expressed as (a) per $100 \mathrm{mg}$ testis and (b) per $\mathrm{mg}$ protein, in the testis after partial body $\gamma$-irradiation of rats at different temperatures. Each point represents the mean for six irradiated rats and is based on three to five analyses. $O, 720 \mathrm{R}$ at $35 \pm 4^{\circ} \mathrm{C}$ (range 30 to $40^{\circ} \mathrm{C}$ ); $\bullet, 2000 \mathrm{R}$ at $35 \pm 4^{\circ} \mathrm{C} ; \triangle, 2000 \mathrm{R}$ at $18 \pm 6^{\circ} \mathrm{C}$ (range 12 to $25^{\circ} \mathrm{C}$ ). The hatched area represents the mean \pm S.D. for normal rats.

The environmental conditions in which the animals were maintained seemed to modify the radiosensitivity of testicular acid phosphatase. At the lethal dose of $2000 \mathrm{R}$ and the higher environmental temperature, the activity of the enzyme did not change over the first 5 days but subsequently declined within 10 days and maintained a constant value thereafter (Text-fig. 2). At a low environmental temperature, however, the rise in the activity within the first 


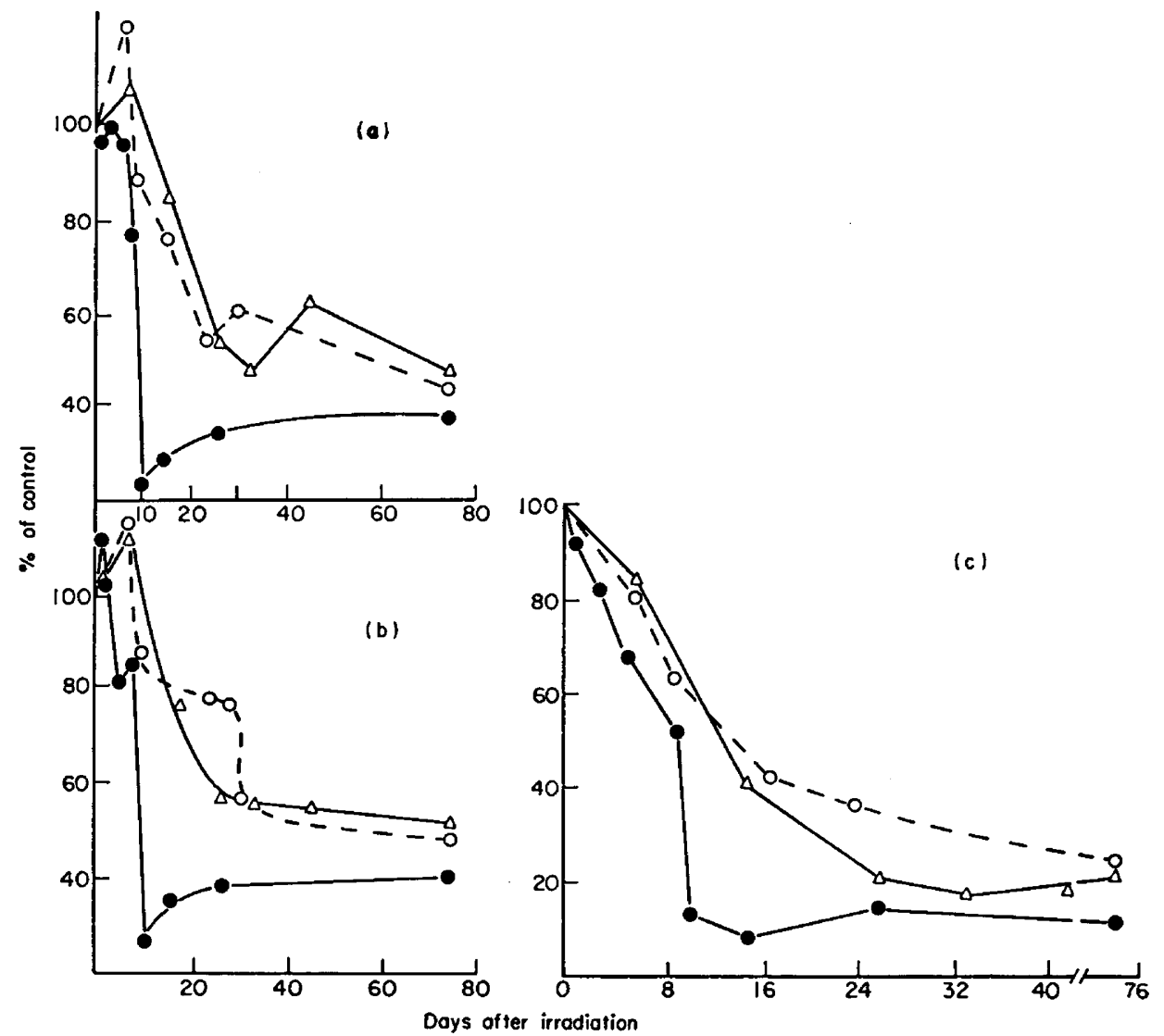

Text-fig. 2. Acid phosphatase activity, expressed as a $\%$ of the control values (a) per mg protein; (b) per $100 \mathrm{mg}$ testis; (c) per testis, in the testis after partial body $\gamma$-irradiation of rats at different temperatures. Each point represents six irradiated and six control rats and is based on three to five analyses. $0,720 \mathrm{R}$ at $35 \pm 4^{\circ} \mathrm{C} ; \bullet, 2000 \mathrm{R}$ at $35 \pm 4^{\circ} \mathrm{C} ; \Delta$, $2000 \mathrm{R}$ at $18 \pm 6^{\circ} \mathrm{C}$.

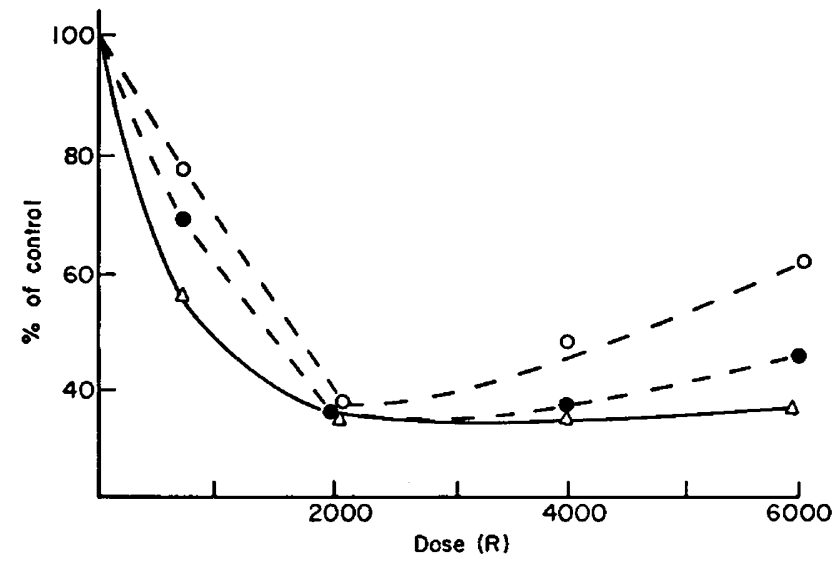

TexT-FIG. 3. Acid phosphatase activity expressed as a $\%$ of the control values, in the rat testis after various doses of partial body $\gamma$-irradiation. Each point represents six irradiated and six control rats and is based on six analyses. $O$, Units/mg protein; $\bullet$, units/mg tissue; $\Delta$, units/testis. 
week was followed by a decline within 24 days. A similar decline after an initial rise in acid phosphatase activity was observed at a dose of $720 \mathrm{R}$ but at a higher environmental temperature.

On subcellular fractionation, the acid phosphatase activity was associated mainly with Fractions I and III which were rich in nuclear and microsomal contents respectively. Little activity was associated with Fraction II which mainly contained mitochondria (Table 1). Irradiation produced different types of response from the microsomal and nuclear enzymes depending on the dose and the time of irradiation, i.e. the activity of the nuclear enzyme declined whereas that of the microsomal enzyme was enhanced 5 days after irradiation at $2000 \mathrm{R}$. After irradiation at $720 \mathrm{R}$, the cytoplasmic acid phosphatase was reduced on the 30 th day, at a time when irradiated interstitial cells showed enhanced activity $(89.8 \pm 14.0$ units/mg protein; $P<0.05)$ and

Table 1. Subcellular distribution of acid phosphatase in control and irradiated rat testes

\begin{tabular}{|c|c|c|c|c|c|}
\hline & \multicolumn{3}{|c|}{ Experiment 1} & \multicolumn{2}{|c|}{ Experiment 2} \\
\hline & $720 R^{*}$ & $2000 R^{*}$ & $\begin{array}{c}\text { Sham- } \\
\text { irradiated }\end{array}$ & $720 R \dagger$ & $\underset{\text { Sham- }}{\text { irradiated }}$ \\
\hline $\begin{array}{l}\text { Whole testis } \\
\text { Units } / 100 \mathrm{mg} \text { tissue } \\
\text { Units/mg protein }\end{array}$ & $\begin{array}{r}139.0 \\
28.9\end{array}$ & $\begin{array}{r}122 \cdot 0 \\
28.0\end{array}$ & $\begin{array}{r}113 \cdot 0 \\
25 \cdot 1\end{array}$ & $\begin{array}{l}86 \cdot 2 \\
25 \cdot 5\end{array}$ & $\begin{array}{r}121 \cdot 2 \\
33 \cdot 0\end{array}$ \\
\hline $\begin{array}{l}\text { Nuclear fraction }(\mathrm{I}) \\
\text { Units/100 mg tissue } \\
\text { Units/mg protein }\end{array}$ & $\begin{array}{r}10 \cdot 0 \\
9 \cdot 0\end{array}$ & $\begin{array}{l}34 \cdot 6 \\
27 \cdot 6\end{array}$ & $\begin{array}{l}39 \cdot 1 \\
31 \cdot 7\end{array}$ & $\begin{array}{l}18 \cdot 0 \\
28 \cdot 1\end{array}$ & $\begin{array}{l}35 \cdot 5 \\
43 \cdot 2\end{array}$ \\
\hline $\begin{array}{l}\text { Mitochondrial fraction (II) } \\
\text { Units/100 mg tissue } \\
\text { Units/mg protein }\end{array}$ & $\begin{array}{l}11 \cdot 0 \\
16 \cdot 0\end{array}$ & $\begin{array}{l}11 \cdot 5 \\
13 \cdot 3\end{array}$ & $\begin{array}{r}8 \cdot 7 \\
12 \cdot 6\end{array}$ & $\begin{array}{l}2 \cdot 2 \\
6.8\end{array}$ & $\begin{array}{r}4 \cdot 5 \\
15 \cdot 0\end{array}$ \\
\hline $\begin{array}{l}\text { Microsomal fraction (III) } \\
\text { Units/100 mg tissue } \\
\text { Units/mg protein }\end{array}$ & $\begin{array}{r}117.4 \\
48.3\end{array}$ & $\begin{array}{r}152.6 \\
62.7\end{array}$ & $\begin{array}{r}117.0 \\
48.1\end{array}$ & $\begin{array}{l}91 \cdot 4 \\
55.7\end{array}$ & $\begin{array}{l}201.0 \\
121.0\end{array}$ \\
\hline
\end{tabular}

* Killed 5 days after irradiation.

$\dagger$ Killed 30 days after irradiation.

seminiferous tubules gave a negative response $(31 \cdot 0 \pm 5 \cdot 1$ units $/ \mathrm{mg}$ protein; $P<0.01)$ compared to that of the controls $(61.8 \pm 12.0$ units/mg protein and $76 \cdot 0 \pm 15 \cdot 2$ units $/ \mathrm{mg}$ protein respectively).

\section{Acid deoxyribonuclease II}

The mean activity ( \pm S.D.) in the supernatant from centrifuged homogenates of normal rat testes was $0.195 \pm 0.03$ units $/ 100 \mathrm{mg}$ fresh tissue and 0.042 \pm 0.004 units $/ \mathrm{mg}$ protein (Text-fig. 4). As early as 4 to $6 \mathrm{hr}$ after irradiation, the activity in the fresh tissue supernatants was 0.27 units in rats irradiated at $720 \mathrm{R}$ compared to 0.20 units in the control rats. The difference in the activity of the enzyme in the fresh supernatants of testes from control and irradiated rats was more than twice the standard deviation $(P<0.05)$. After an initial increase within 4 to $6 \mathrm{hr}$ at $720 \mathrm{R}$ and $16 \mathrm{hr}$ at $2000 \mathrm{R}$, acid DNAse activity tended to be normal on Days 4 and 7, respectively, at lethal and sub-lethal 
doses. Thereafter, following an increase, the activity continued to show a similar pattern over a period of 30 days and 11 months (Text-fig. 5). During subsequent periods, the over-all increase per $\mathrm{mg}$ testis and per $\mathrm{mg}$ protein at $2000 \mathrm{R}$ was well-marked for those rats subjected to $720 \mathrm{R}$.

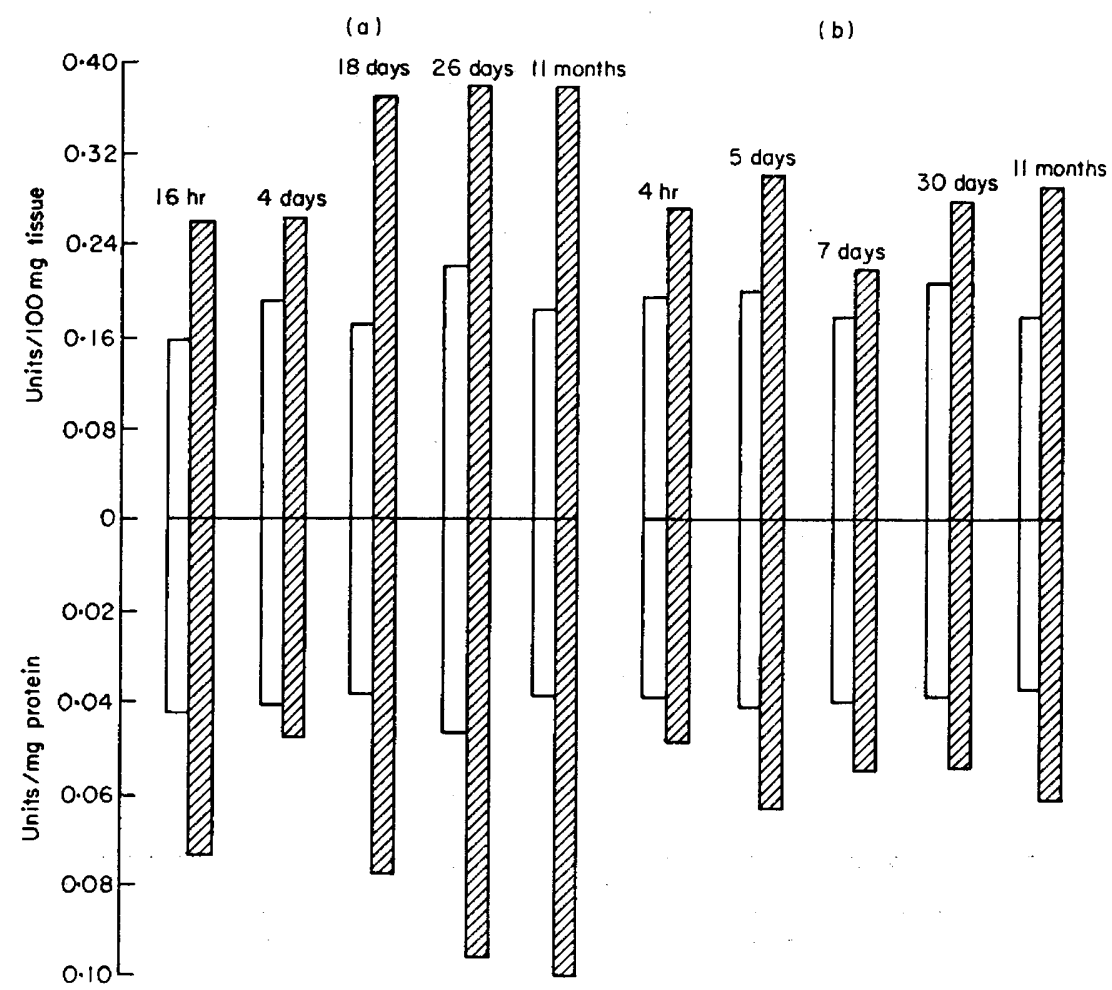

Text-FIG. 4. The activity of acid deoxyribonuclease in the testis of control rats (open columns) and of rats at different times after (a) $2000 \mathrm{R}$ and (b) $720 \mathrm{R}$ (hatched columns). Each column represents the mean for six irradiated and four controls rats and is based on four analyses.

\section{DISGUSSION}

\section{Acid phosphatase}

Studies on the effects of whole body irradiation on lysosomal enzymes in lymphoid tissues have indicated that the primary cause of death of the cells after irradiation may be due to the release of hydrolytic enzymes from the damaged lysosomes (Okada, 1970). The increase in the activity of acid phosphatase during the first week of irradiation may, therefore, be due to lysosomal breakdown of testicular cells or to increased phagocytic activity of the Sertoli cells (Nebel, 1959; Hugon \& Borgers, 1966). Blackshaw \& Hamilton (1970) suggested that the initial lesion during heat treatment may affect the cell wall of late pachytene spermatocytes, leading to major ionic imbalance and release of lysosomal enzymes with subsequent dissolution of the cell. Other studies of the local effects of heat on the testis suggest loss of acid phosphatase from the 


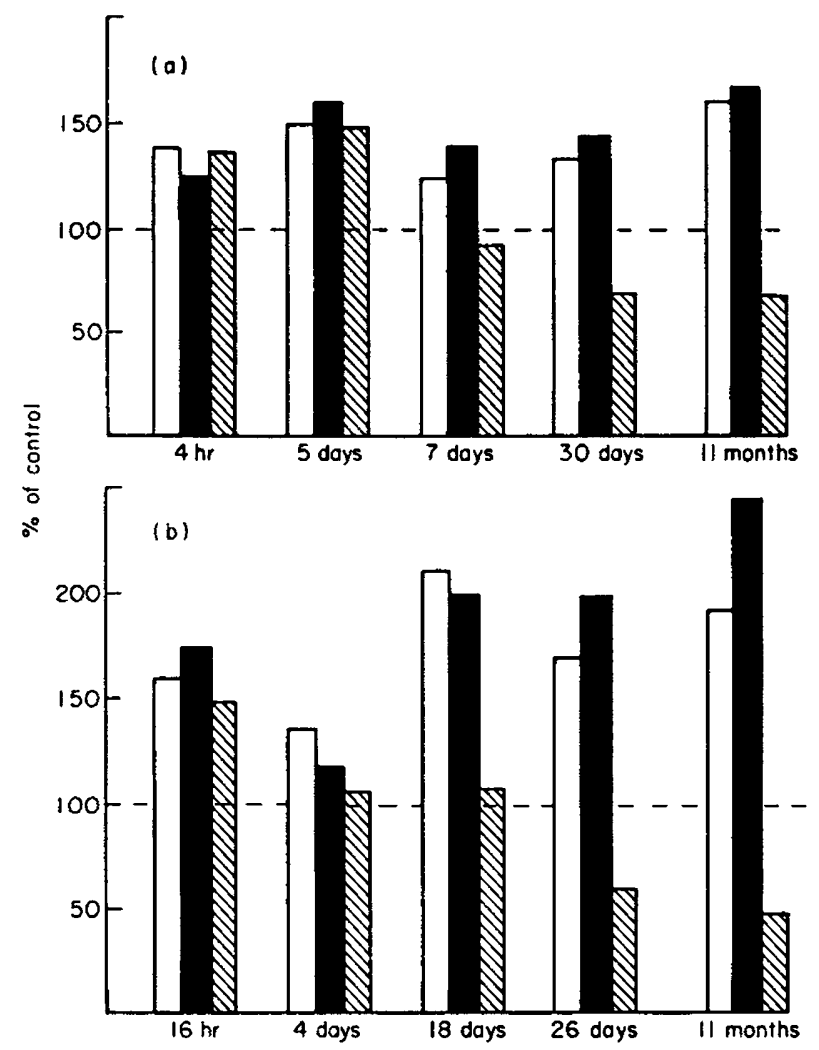

TExT-F1G. 5. The activity of acid deoxyribonuclease expressed as a $\%$ of the control values in units/100 $\mathrm{mg}$ tissue (open columns), units/mg protein (solid columns) and units/testis (hatched columns) on different days after partial body $\gamma$-irradiation at (a) $720 \mathrm{R}$ and (b) $2000 \mathrm{R}$. Each column represents the mean for six irradiated and four control rats and is based on four analyses.

tubules (Bawa, Kanwar \& Singal, 1971) and an increased concentration in the interstitium (Waites \& Ortavant, 1968; Blackshaw, 1970). It appears that the response of rat testicular acid phosphatase to radiation resembles the response to local hyperthermia in the seminiferous tubules (Bawa et al., 1971) and interstitium (Waites \& Ortavant, 1968).

Ellis \& Berliner (1963) reported a triphasic response of androgen production (including testosterone) to radiation. It was observed that androgen production increased during the first week after total body irradiation of mice. Since it has been suggested that lysosomes are involved in steroid synthesis and are inhibitory to androgen production (Frank \& Christensen, 1968; Dietert \& Scallen, 1969; Russo, 1970), it is possible that the enhanced activity of lysosomal enzymes during the first week is in some way related to the androgen production.

The studies on teased seminiferous tubules, however, suggest that the depleting action of the enzyme resides in this part of the testis and in the isolated nuclei from the tissue homogenates from rats 30 days after irradiation (Table 1). In rat testes, acid phosphatase has been shown to be present in lysosomes of 
Sertoli cells, spermatocytes and spermatozoa (Males \& Turkington, 1971). The late response of testicular acid phosphatase to radiation appears to be due to the disappearance of late spermatocytes and spermatids (Gupta \& Bawa, 1974c). Rappoport (1959) has reported decreased production of nucleoside esters in testes $24 \mathrm{hr}$ after irradiation. Since acid phosphatase plays an important rôle in producing orthophosphate, it appears that the loss of acid phosphatase in the nuclear fraction of the testis is responsible for reduced synthesis of the nucleotide esters required in the synthesis of nucleic acids and in the differentiation of the germ cells. This suggests that nuclear and microsomal enzymes may be operative in damaging the germ cells through different mechanisms. The increase in the microsomal fraction can be related to the release of lytic enzyme due to fragility of the lysosomes in the cells of the tubules. Lack of enhanced enzymatic activity in the first week at the high environmental temperature and a dose of $2000 \mathrm{R}$ was presumably due to the sensitizing action of temperature in radiation injury and to the sudden disappearance of spermatocytes and spermatids. The effect of temperature during and after irradiation is well documented. Many controversies regarding the radiosensitivity of the germ cells can thus be resolved if the total conditions of the experiment are stated.

\section{Acid deoxyribonuclease}

The high requirement of substrate by testicular DNAse suggests that the enzyme has a high $\mathrm{K}_{\mathrm{m}}$ value and forms an unstable enzyme-substrate complex. Though acid phosphatase activity continued to decline after the first week of irradiation, acid DNAse exhibited an upward trend within hours of commencing irradiation. Levels tended to decrease to normal within 7 days and thereafter started to increase again. The levels by Day 4 after a dose of $2000 \mathrm{R}$ and by Day 7 after $720 \mathrm{R}$ presumably coincided with maximum damage to the germ cells. Once the germ cells were lost, the activity started to increase because of concentration effects of Sertoli and interstitial cells per unit mass of the testis. The subsequent increase in the activity of acid DNAse seems to be distinctly related to phagocytic activity of non-germinal cells which predominate at a time when the seminiferous tubules are devoid of germ cells (Gupta \& Bawa, 1974c, 1975). The phagocytic activity of testis may be due to an imbalance of electrolytes (Gupta \& Bawa, 1974a) across the germinal and nongerminal cells of the seminiferous tubules. Lacy (1964) found that the effects of irradiation and oestrogens on the testis led to the accumulation of lipids in the Sertoli cells, originating perhaps from degenerating germ cells (Lacy \& Lofts, 1961). Hugon \& Borgers (1966) noted dissolution of spermatogonia within a few hours of irradiation and phagocytosis was accompanied by the appearance of lysosomes in the Sertoli cells which, at this stage, showed a strong acid phosphatase reaction. The observations of the present study on the stimulated activity of acid phosphatase and DNAse during the first week and the increased activity of DNAse subsequently are in agreement with the observations of Lacy \& Lofts (1962) and Hugon \& Borgers (1966). We have suggested that irradiation of rat testes is associated with hyperplasia of the interstitium and the accumulation of glycogen in the non-germinal cells though, in normal 
testes, these cells could not be shown to contain enough glycogen (Gupta \& Bawa, 1974c). It is possible that glycogen is acting as a reserve substrate for the phagocytic activity of Sertoli cells. According to Blackshaw \& Hamilton (1970), however, increased activity of lysosomal enzymes with ionic imbalance is an indication of some defect of the late pachytene spermatocytes. A point of difference between the two lysosomal enzymes after the first week can be resolved if it is assumed that the late germ cells are richer in acid phosphatase and thus subsequent loss of acid phosphatase is primarily associated with the loss of the germinal cell population (Males \& Turkington, 1971).

\section{ACKNOWLEDGMENTS}

The authors wish to express their gratitude to the Director, Dr P. N. Chhuttani, and to Dr B. D. Gupta, Associate Professor of the Institute of Postgraduate Medical Education and Research, Chandigarh, for providing irradiation facilities.

\section{REFERENGES}

Alekseeva, A. M. \& Timofeeva, N. M. (1959) Alterations in chemical composition of the testis in atrophy induced by ionizing radiation. Vop. med. Khim. 5, 48-53.

Bawa, S. R., Kanwar, K. C. \& Singal, P. K. (1971) Unilateral hyperthermic shocks to rat testis. J. Reprod. Fert. 25, 271-273.

Blackshaw, A. W. (1970) Histochemical localization of testicular enzymes. In The Testis, Vol. II, pp. 73-123. Eds. A. D. Johnson, W. R. Gomes and N. L. VanDemark. Academic Press, New York.

Blackshaw, A. W. \& Hamirton, D. (1970) The effect of heat on hydrolytic enzymes and spermatogenesis in the rat testis. 7. Reprod. Fert. 22, 569-572.

Gr.Ausen, J. (1969) Lactic dehydrogenase isoenzymes of sperm cells and testis. Biochem. 7. 111, 209-218.

Dietert, S. E. \& SaAlien, I. J. (1969) An ultrastructural and biochemical study of the effect of three inhibitors of cholesterol biosynthesis upon murine adrenal gland and testis. I. Histochemical evidence for a lysosome response. 7. Cell Biol. 40, 44-66.

Elis, L. G. \& Berliner, D. L. (1963) The effects of ionizing radiations on endocrine cells. I. Steroid biotransformations and androgen production by testes from irradiated mice. Radiat. Res. 20, 549-563.

Fiske, G. H. \& Subbarow, Y. (1925) Colorimetric determination of phosphorus. 7. biol. Chem. 66, $375-400$.

Frank, A. L. \& Ghristensen, A. K. (1968) Localization of acid phosphatase in lipofuscin granules and possible autophagic vacuoles in interstitial cells of the guinea pig testes. 7. Cell Biol. 36, $1-13$.

Gupta, G. S. \& BAwa, S. R. (1970) Secretory activities of prostates and seminal vesicles after the localized X-irradiation of rat testes. F. Reprod. Fert. 21, 329-331.

Gupta, G. S. \& BAwA, S. R. (1971) Phosphatases in testes and epididymides of albino rats after partial body $\gamma$-irradiation. 7 . Reprod. Fert. 27, $451-454$.

Gupta, G. S. \& BAWA, S. R. (1974a) Electrolyte imbalance and adenosine triphosphatase activity in gamma irradiated rat testes. Proc. 7th All India Symp. Ind. biophys. Soc., New Delhi, pp. 76, Abstr.

Gupta, G. S. \& BAwA, S. R. (1974b) Testicular nucleic acids and testis pituitary axis following the local body gamma irradiation. Proc. 5th Asia and Oceania Congr. Endocrinology, Chandigarh, pp. 228-237.

GuptA, G. S. \& BAWA, S. R. (1974c) Glycogen in non-germinal cells of rat testes following gamma irradiation. 7. Reprod. Fert. 41, 185-188.

Gupta, G. S. \& BAwA, S. R. (1975) Radiation effects on testes. II. Incorporation of ${ }^{65} \mathrm{Zn}$ after partial body gamma-irradiation of rats. J. Reprod. Fert. 42, 29-34.

HALL, P. F., IRBy, D. C. \& DE Kretser, D. M. (1969) Conversion of cholesterol to androgens by rat testes: comparison of interstitial cells and seminiferous tubules. Endocrinology, 84, 488-496.

Hugon, J. \& Borgers, M. (1966) Ultrastructural and cytochemical changes in spermatogenic and Sertoli cells of whole body irradiated mice. Anat. Rec. 155, 15-19. 
Iто, M. (1966) Histochemical observations of oxidative enzymes in irradiated testis and epididymis. Radiat. Res. 26, 266-277.

KuRnick, N. B. \& SANDEEN, G. (1960) Acid deoxyribonuclease assay by methyl green method. Biochim. biophys. Acta, 39, 226-231.

LACY, D. (1964) Comparison of effects produced by doses of ionizing radiation and oestrogenic hormone on seminiferous tubules of rat testis. In Effects of Ionizing Radiation on the Reproductive System, pp. 189-212. Eds W. D. Garlson and F. X. Gassner. Pergamon Press, Oxford.

LACY, D. \& LoFTs, B. (1962) The use of ionizing radiation and oestrogen treatment in the detection of hormone synthesis by the Sertoli cells. $\mathcal{F}$. Physiol., Lond. 161, 23p.

Lowry, O. H., Rosebrough, N. J., Farr, A. L. \& Randall, R. J. (1951) Protein measurement with the Folin phenol reagent. F. biol. Chem. 193, 265-275.

Males, J. L. \& Turkington, R. W. (1971) Hormonal control of lysosomal enzymes during spermatogenesis in the rat. Endocrinology, 88, 579-588.

Nebre, B. R. (1959) Fine structure of chromosomes in man and other metazoa and testicular recovery from X-rays in mammals. Proc. 2nd U.N. Int. Conf. on Peaceful Uses of Atomic Energy, Geneva, pp. 1-9. US Atomic Energy Commission.

Okada, S. (1970) Radiation Biochemistry, Vol. I, Cells. Academic Press, New York.

Pecora, P. \& Arate, L. (1964) $\beta$-Glucuronidase and esterase activities of rat testis after X-ray treatment. J. Reprod. Fert. 8, 281-285.

RAPPOPORT, D. S. (1959) Formation of phosphate esters from purine nucleosides by testicular extracts from X-irradiated rats. Radiat. Res. 11, 229-241.

Russo, J. (1970) Gircadian rhythm of acid phosphatase in mouse testis lysosomes. F. Reprod. Fert. 23, 21-24.

SAPSFORD, C. S. (1965) The synthesis of DNA and nuclear protein by gonocytes in the testis of normal and X-irradiated rats. Aust. F. biol. Sci. 18, 653-663.

Steinberger, E. (1964) Effects of sex steroids on endogenous respiration of X-irradiated testis. In Effects of Ionizing Radiation on the Reproductive System, pp. 213-217, Eds. W. D. Carlson and F, X. Gassner. Pergamon Press, Oxford.

Steingerger, E. \& Nelson, W. O. (1957) The effect of furadoxyl treatment and X-irradiation on the hyaluronidase concentration of rat testis. Endocrinology, 60, 105-117.

StEINBERGER, E. \& WAGNER, G. (1961) Observations on the endogenous respiration of rat testicular tissue. Endocrinology, 69, 305-311.

VAlenta, M. \& Kolousek, J. (1963) The influence of ionizing radiation on nucleic acids vitality and fecundating ability of male sexual cells. Int. F. Radiat. Biol. 6, 81-91.

Wartes, G. M. H. \& Ortavant, R. (1968) Effet précoce d'une brève élévation de la température testiculaire sur la spermatogénèse du bélier. Annls Biol. anim. Biochim. Biophys. 8, 323-331. 